\title{
Characterization of ten polymorphic microsatellite markers for the endemic Chapman's ringlet, Erebia palarica (Lepidoptera: Nymphalidae)
}

\author{
Marta VILA ${ }^{1}$, TomÁs LATASA ${ }^{2}$, JuAn J. PINO ${ }^{3}$ and Georges VERHULST ${ }^{4}$ \\ ${ }^{1}$ Department of Molecular and Cell Biology, University of A Coruna, Faculty of Sciences, Campus Zapateira, \\ E-15008, A Coruna, Spain; e-mail: mvila@udc.es \\ ${ }^{2}$ General Urritia 61F, E-26006, Logrono, Spain \\ ${ }^{3}$ Department of Animal Biology and Ecology, University of Vigo, Faculty of Biology, E-36310, Vigo, Spain \\ ${ }^{4} 186$ Avenue Van Becelaere, 1170 Brussels, Belgium
}

Key words. Erebia palarica, Erebia meolans, microsatellites, Lepidoptera, Nymphalidae, Satyrinae

\begin{abstract}
Ten polymorphic microsatellite loci were developed for the butterfly Erebia palarica (Nymphalidae, Satyrinae), endemic to NW Spain. Polymorphism for 20 individuals from a NW Spanish population (Ancares) and 15 more from two other nearby localities (Courel, Trevinca) was assessed. Overall, the number of alleles per locus ranged from six to 24. Ancares showed an average number of alleles per locus of $14.30(S D=5.32)$, observed heterozygosity of $0.753(S D=0.14)$ and unbiased expected heterozygosity of $0.818(S D=0.114)$. Genotypic frequencies conformed to the Hardy-Weinberg equilibrium at Ancares, and there was no evidence of linkage disequilibrium. Multilocus genotypes resulting from this set of markers will be useful for determining genetic diversity and differentiation within and among populations of this local endemic butterfly in NW Spain. Of the six loci amplified in the closely related species, Erebia meolans, five were polymorphic.
\end{abstract}

\section{INTRODUCTION}

Many butterflies in the Paleartic, including the genus Erebia Dalman (Nymphalidae: Satyrinae) in southern and central Europe, are considered to be glacial relicts because of their montane and higher altitude distribution (Warren, 1936). Species of Erebia usually show noticeable intraspecific phenotypic variation in wing size and pattern, which has led to a considerable number of subspecies [e.g., four within Erebia euryale (revised by Schmitt \& Haubrich, 2008)] and provided interesting scenarios for studying incipient speciation (Vila et al., 2005). There are various studies on the phylogeny and population genetics of Erebia species. They were driven by the need to (i) unravel the phylogenetic relationships of complex groups [Albre et al. (2008) by sequencing mitochondrial DNA], (ii) infer the phylogeographic pattern of a given species [Schmitt \& Seitz (2001) by using allozymes], or (iii) define conservation units [Vila et al. (2006) by comparing mitochondrial sequences and nuclear microsatellites]. This genus underwent a rapid diversification, possibly because of the spatial and temporal specialization of many of its species, which resulted in a large number of endemic taxa (revised by Martin et al., 2000).

The butterfly Erebia palarica Chapman 1905, also known as Chapman's ringlet, is endemic to Spain. It is the largest species of the genus in Europe (Tolman \& Lewington, 1997). This Satyrinae species occurs in NW Spain at altitudes above $1000 \mathrm{~m}$ (Fig. 1). As its congeneric species $E$. palarica is a host plant generalist, i.e., not dependant on any particular species of Poaceae for its larval development (Munguira et al., 1997). Some of the populations of this ringlet butterfly may have been isolated since the Upper Pleistocene, as suggested by the pattern found in conspecific and sympatric species (Vila et al., 2005). Estimates of geneflow between these localities are needed in order to address several conservation issues, such as the putative inclusion of the populations occurring at the westernmost fringes of the Cantabrian Mountains (Fig. 1) on the Galician Red List (i.e., catalogue of species legally protected in the most northwesterly region of Spain).

From a conservation perspective, the levels of geneflow, dispersal and/or differentiation between demes or populations are among the main objectives of a molecular genetics approach. Datasets suitable for these calculations may have been collected using different methods, such as the nuclear markers mentioned above, or Amplified Fragment Length Polymorphism (AFLPs) (Krumm et al., 2008), Random Amplification of Polymorphic DNA (RAPDs) (Vandewoestijne \& Baguette, 2004), Inter Simple Sequence Repeats (ISSR) (Roux et al., 2007) and/or Single Nucleotide Polymorphism (SNPs) (Orsini et al., 2008).

Nuclear microsatellites (highly polymorphic and single locus DNA markers) offer many advantages (revised by Selkoe \& Toonen, 2006). Like other codominant markers, such as allozymes and SNPs, microsatellites allow the calculation of allele frequencies. In addition, they usually have a mutation rate per generation of the order of $10^{-4}$, which is faster than that of allozymes or SNPs (Brumfield et al., 2003). This is a highly attractive feature when identifying individuals and parentage based on the "exclusion principle". Despite the advantages of SNPs over micro- 

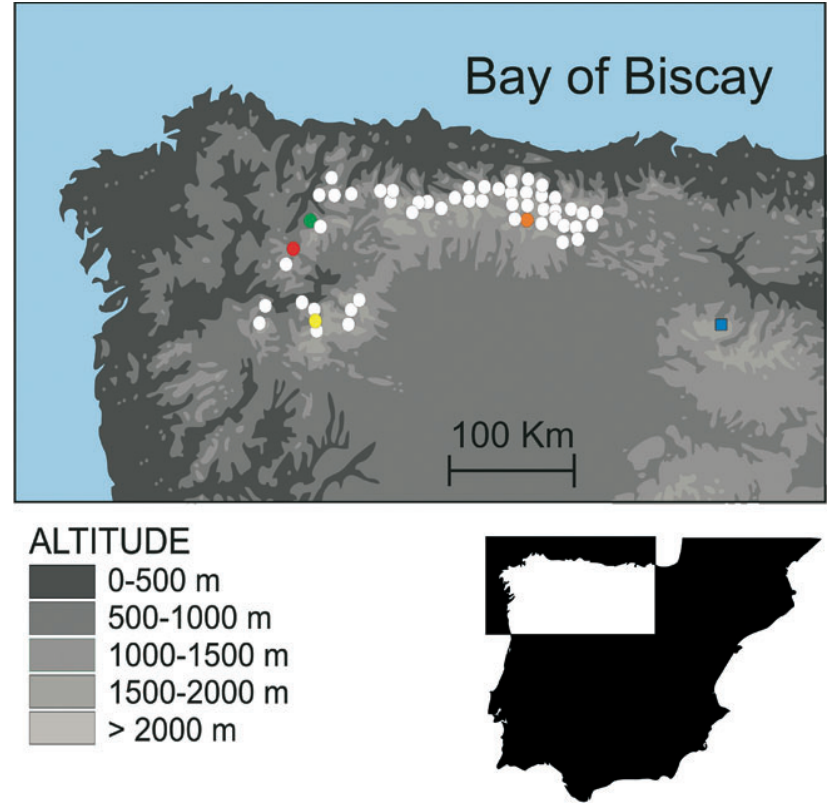

Fig. 1. Map showing the distribution (white circles) of Erebia palarica, which is endemic to NW Iberia (adapted from GarcíaBarros et al., 2004), and the sites where the individuals analysed in the present study (colour circles) were collected. Yellow (Trevinca), red (Courel), green (Ancares), orange (Monteviejo), blue (Valdezcaray). The blue square is the locality where samples of E. meolans used in this study were collected. It is not part of the distribution area of E. palarica.

satellites, more SNPs are required than microsatellites for the same power of exclusion (Weller et al., 2006). Therefore, microsatellite DNA markers seem to be an appropriate choice when the objectives of the study are the determination of population structure and individual identification. Unfortunately, the development of microsatellites for Lepidoptera has proved difficult and not as successful as for other taxonomic groups (Zhang, 2004).

We aimed to identify an appropriate set of genetic markers to (i) investigate the genetic diversity and structure of this species throughout its distribution (i.e., NW Spain) and (ii) perform parental analysis and/or individual identification of Erebia palarica. Here we describe the isolation and characterization of ten polymorphic microsatellite markers for Chapman's ringlet and indicate their effectiveness in identifying patterns of genetic diversity and parental analysis. For this, we genotyped 20 indi- viduals collected from one NW Spanish population (Ancares, Lugo province). Additionally, 10 specimens of E. palarica from another locality in the same province (Courel) and five more individuals from the Galician population at Trevinca (Ourense province) were also genotyped. We tested the usefulness of these markers on a closely related species with a much wider distribution: the Piedmont ringlet Erebia meolans de Prunner 1798.

\section{MATERIAL AND METHODS}

Most specimens were collected by hand netting in July 2007 (Table 1) and preserved in absolute ethanol until used in the analysis. Genomic DNA was extracted from the thorax of $E$. palarica using the QIAGEN DNeasy ${ }^{\circledR}$ Tissue Kit (Qiagen Iberia S.L., Madrid, Spain). An enriched library was made by Ecogenics $\mathrm{GmbH}$ (Zurich, Switzerland) from size selected genomic DNA ligated into SAULA/SAULB-linker (Armour et al., 1994) and enriched by magnetic bead selection with biotinlabelled (GTAT) $)_{7},(\mathrm{GATA})_{7},(\mathrm{GT})_{13}$ and $(\mathrm{CT})_{13}$ oligonucleotide repeats (Gautschi et al., 2000a, b). Of 1126 recombinant colonies screened, 208 gave a positive signal after hybridization. Plasmids from 205 positive clones were sequenced and primers were designed for 37 microsatellite inserts, of which 27 were tested for polymorphism. One primer pair was excluded because it was monomorphic. Eleven other primer pairs did not amplify in a first set of 15 individuals or resulted in a complicated allelic pattern, difficult to interpret and were therefore not used in the present study. Five primer pairs were excluded because they were not appropriate for subsequent multiplex PCR. Ten microsatellite loci were reliably scored and polymorphic.

Markers were amplified using Polymerase Chain Reaction. PCR conditions were designed for multiplexing of up to four loci per reaction. Each of the three multiplex PCR amplifications was optimised to be performed in a $10 \mu \mathrm{L}$ reaction volume. Forward primers were fluorescent-labelled with NED, HEX or 6-FAM dyes (Applied Biosystems (ABI), Madrid, Spain) (Table 2).

PCR protocol was similar for the three multiplex reactions: 0.2-10 ng of DNA, $0.5 \mathrm{U}$ HotStar Taq DNA polymerase, $1 \times$ PCR buffer with $1.5 \mathrm{mM} \mathrm{MgCl}_{2}, 200 \mu \mathrm{M}$ of each dNTP (QIAGEN HotStar Taq Mastermix), $0.3 \mu \mathrm{M}$ of forward and reverse primers each. Multiplex 1 and 2 amplified three loci, whereas multiplex 3 amplified four loci (Table 2). The thermal treatment was the same for the three multiplex reactions: 35 cycles with $94^{\circ} \mathrm{C}$ for $30 \mathrm{~s}, 56^{\circ} \mathrm{C}$ for $90 \mathrm{~s}$, and $72^{\circ} \mathrm{C}$ for $60 \mathrm{~s}$. Before the first cycle, a prolonged denaturation step $\left(95^{\circ} \mathrm{C}\right.$ for $15 \mathrm{~min}$ ) was included and the last cycle was followed by a 30 min extension at $60^{\circ} \mathrm{C}$.

Amplified PCR products $(1.2 \mu \mathrm{L})$ were mixed with $16 \mu \mathrm{L}$ formamide containing GENESCAN-500 (ROX) Size Standard

TABLE 1. Details of the Spanish sampling sites and specimens analysed in the present study, and genetic descriptive estimators at population level $(N \geq 10)$.

\begin{tabular}{lccccccccc}
\hline Species & Locality & Province & Latitude & Longitude & $N$ & Sex & $A R$ & $H_{\mathrm{E}}$ & $F_{\text {IS }}$ \\
\hline E. palarica & Ancares & Lugo & $42^{\circ} 49^{\prime} \mathrm{N}$ & $6^{\circ} 54^{\prime} \mathrm{W}$ & 20 & $1 \uparrow, 190^{\star}$ & $8.39 \pm 2.32$ & $0.818 \pm 0.114$ & 0.08 \\
E. palarica & Courel & Lugo & $42^{\circ} 36^{\prime} \mathrm{N}$ & $7^{\circ} 05^{\prime} \mathrm{W}$ & 10 & $39,7 \delta^{\star}$ & $6.7 \pm 2.06$ & $0.812 \pm 0.088$ & $0.162^{\mathrm{a}}$ \\
E. palarica & Trevinca & Ourense & $42^{\circ} 12^{\prime} \mathrm{N}$ & $6^{\circ} 53^{\prime} \mathrm{W}$ & 5 & $\wp$ & - & - & - \\
E. palarica & Monteviejo & León & $42^{\circ} 57^{\prime} \mathrm{N}$ & $4^{\circ} 54^{\prime} \mathrm{W}$ & 4 & $\delta^{\star}$ & - & - & - \\
E. meolans & Valdezcaray & La Rioja & $42^{\circ} 14^{\prime} \mathrm{N}$ & $2^{\circ} 58^{\prime} \mathrm{W}$ & 10 & $\wp$ & $5.8 \pm 3.27^{\mathrm{b}}$ & $0.69 \pm 0.267^{\mathrm{b}}$ & $0.246^{\mathrm{a}, \mathrm{b}}$ \\
\hline
\end{tabular}

Sample sizes $(N)$, average allelic richness per locus per population based on 10 individuals $(A R)$, unbiased expected heterozygosity $\left(H_{\mathrm{E}}\right)\left( \pm\right.$ standard deviation) and inbreeding coefficient $\left(F_{\mathrm{IS}}\right) .{ }^{\text {a }}$ Significant heterozygote deficiency (adjusted nominal level $\left.=0.0025\right)$;

${ }^{\mathrm{b}}$ Based on five polymorphic markers (Table 2). 
TABLE 2. Characteristics of the ten polymorphic microsatellite loci developed for Erebia palarica.

\begin{tabular}{|c|c|c|c|c|c|c|c|c|c|c|c|c|}
\hline \multirow{2}{*}{ Locus } & \multirow{2}{*}{$\begin{array}{l}\text { GenBank } \\
\text { Accession }\end{array}$} & \multirow{2}{*}{ Repeat motif } & \multirow{2}{*}{ Primer sequence (5'-3') } & \multicolumn{7}{|c|}{ Erebia palarica } & \multicolumn{2}{|c|}{$\begin{array}{l}\text { Erebia } \\
\text { meolans }\end{array}$} \\
\hline & & & & MP & Size & $A$ & $H_{\mathrm{E}}$ & $H_{\mathrm{O}}$ & Size’ & $A^{\prime}$ & Size & $A$ \\
\hline EP01 & FJ965448 & $(\mathrm{TG})_{2} \mathrm{TC}(\mathrm{TG})_{14} \mathrm{CG}(\mathrm{TG})_{7}$ & $\begin{array}{l}\text { F:CTAATATTATAAATGCCAAAGTGTGC(NED) } \\
\text { R:AATTCGTCGAAAATGGGTTG }\end{array}$ & 11 & $107-153$ & 11 & 0.713 & 0.65 & $107-157$ & 13 & 98 & 1 \\
\hline EP06 & FJ965449 & $\mathrm{AA})_{2} \mathrm{TACT}(\mathrm{CA})_{2} \mathrm{TA}(\mathrm{CA})_{15} \mathrm{CT}(\mathrm{CA})_{2}$ & $\begin{array}{l}\text { F:CACCCAGTAAGCCAGCAATC(HEX) } \\
\text { R:TCATACAGGCATGCAATTGAG }\end{array}$ & 11 & $137-221$ & 14 & 0.937 & 0.842 & $137-221$ & 18 & - & - \\
\hline EP10 & FJ965450 & $(\mathrm{AG})_{21}$ & $\begin{array}{l}\text { F:TTGGCCATGTGAAAGTTACG(6-FAM) } \\
\text { R:GGTTTTCCGAACCACTCGAC }\end{array}$ & 1 & $193-259$ & 17 & 0.906 & 0.895 & $143-259$ & 24 & - & - \\
\hline EP12 & FJ965451 & $(\mathrm{AC})_{5} \mathrm{CC}(\mathrm{AC})_{13}(\mathrm{GC})_{4} \ldots(\mathrm{CA})_{8}$ & $\begin{array}{l}\text { F:TCGGTCTAGTCTTTGTGGAGTG(NED) } \\
\text { R:AGTTGAGATGCAGTGGCTTG }\end{array}$ & 2 & $167-191$ & 10 & 0.816 & 0.895 & $167-191$ & 11 & $132-151$ & 5 \\
\hline EP13 & FJ965452 & $(\mathrm{CA})_{14}$ & $\begin{array}{l}\text { F:TGTATATCGAGGCAGGTCAGG(HEX) } \\
\text { R:TGTTTATTTCGGTGTAATGTTTGG }\end{array}$ & 2 & $165-177$ & 6 & 0.561 & 0.684 & $165-177$ & 6 & $166-180$ & 5 \\
\hline EP28 & FJ965453 & $(\mathrm{CA})_{24}$ & $\begin{array}{l}\text { F:CAGCGTGGCAATAGATAGGC(6-FAM) } \\
\text { R:TTAAAGGCTATTCGCCATCG }\end{array}$ & 2 & $113-189$ & 11 & 0.816 & $0.6^{\mathrm{b}}$ & $107-189$ & 17 & - & - \\
\hline EP20 & FJ965454 & $(\mathrm{CA})_{23}$ & $\begin{array}{l}\text { F:ATATCGGAAACGCGATGG(HEX) } \\
\text { R:CACGGAGGTCGTCAAAATTC }\end{array}$ & 3 & $115-135$ & 11 & 0.857 & 0.737 & $107-153$ & 13 & - & - \\
\hline EP32 & FJ965455 & $(\mathrm{GT})_{13} \mathrm{TT}(\mathrm{GT})_{10}$ & $\begin{array}{l}\text { F:CGCGTCCAGATTACAATTTC(6-FAM) } \\
\text { R:ACACATTCATGAACAAGATGTTTC }\end{array}$ & 3 & $185-261$ & 14 & 0.936 & $0.526^{\mathrm{a}, \mathrm{b}}$ & b $177-261$ & 20 & $169-217$ & 11 \\
\hline EP33 & FJ965456 & $(\mathrm{CT})_{9} \mathrm{CC}(\mathrm{CT})_{3} \mathrm{CC}(\mathrm{CT})_{12}$ & $\begin{array}{l}\text { F:GGAGGAACTGGCTTATGTTTTATG(NED) } \\
\text { R:TAATGGAAAGGGGTCACAGC }\end{array}$ & 3 & $127-137$ & 6 & 0.780 & 0.75 & $127-139$ & 7 & $87-123$ & 6 \\
\hline EP38 & FJ965457 & $(\mathrm{CA})_{16}$ & $\begin{array}{l}\text { F:GAACATTCTACCCCGAAACG(NED) } \\
\text { R:CCGGCTTTGTAACTGAGAGG }\end{array}$ & 3 & $181-209$ & 10 & 0.860 & 0.947 & 175-209 & 14 & $178-180$ & 2 \\
\hline Total & & & & & & $\begin{array}{c}11 \\
\pm \\
3.43\end{array}$ & $\begin{array}{l}0.818 \\
\pm \\
0.114\end{array}$ & $\begin{array}{c}0.753 \\
\pm \\
0.14\end{array}$ & & $\begin{array}{l}14.3 \\
\pm \\
5.62\end{array}$ & & $\begin{array}{c}5 \\
\pm \\
3.52\end{array}$ \\
\hline
\end{tabular}

PCR conditions for each multiplex (MP) are specified in the text. Number of alleles per locus $(A)$, observed $\left(H_{\mathrm{O}}\right)$ and unbiased expected $\left(H_{\mathrm{E}}\right)$ heterozygosity are reported for the Ancares population. $A$ ' and Size' represent number of alleles per locus and size range (bp) of PCR products based on analysing 35 individuals from three localities. ${ }^{a}$ Significant heterozygote deficiency; ${ }^{\text {b }}$ Showing signs of null alleles.

(ABI) and the genotype was determined on an ABI Prism 3100 Genetic Analyzer using GeneScan Analysis ${ }^{\circledR}$ Software 3.7 and Genotyper ${ }^{\circledR}$ 3.7 Software (ABI). Dilutions of the labelled and unlabelled primers prior to the PCR step were optimized, so that the PCR product may be loaded on the sequencer with no need for further dilution steps. Details of the primer dilutions are available from the authors upon request.

DNA sequences of these ten polymorphic microsatellite markers were confirmed to be unique using BLASTN 2.219 (Zhang et al., 2000). A total of 35 individuals of E. palarica were genotyped for each of the ten loci. Ten individuals of $E$. meolans hispanica collected at La Rioja (Table 1) were genotyped using the same PCR conditions. Numbers of alleles per locus, observed heterozygosities and paternity exclusion probability were estimated using IDENTITY4 (Wagner \& Sefc, 1999). Unbiased expected heterozygosity, analyses of HardyWeinberg (HW) segregations and tests for linkage disequilibrium were computed with FSTAT 2.9.3.2 (Goudet, 2001). The frequency of null alleles was calculated with MICROCHECKER (Van Oosterhout et al., 2004).

\section{RESULTS}

All loci were successfully amplified in the 35 Erebia palarica individuals tested, with the exception of loci EP06, EP10, EP12, EP13, EP20, EP32, and EP38 in one specimen (ANC0723). Each individual had a distinct genotype. Focusing on the Ancares population $(N=20)$, the average number of alleles per locus was $14.30(S D=$ 5.62). Average observed heterozygosity was $0.753(S D=$ 0.14 ) and the average expected heterozygosity reached $0.818(S D=0.114)$ (Table 2$)$. The polymorphism information content (PIC) value for that population ranged from 0.508 (locus EP13, 6 alleles) to 0.903 (locus EP06, 14 alleles). One locus (EP32) showed homozygote excess and deviated significantly from HW expectations after correcting for multiple tests (adjusted $P$-value for $5 \%$ nominal level $=0.005)($ Table 2$)$. Loci EP28 and EP32 showed signs of non amplifying alleles at moderate frequencies in the Ancares population (frequency $=0.12$ and 0.20 , respectively) as revealed by MICRO-CHECKER (Van Oosterhout et al., 2004). However, only EP32 seemed to be affected by null alleles in the Courel population (frequency $=0.19$ ). We observed no deviations from linkage equilibrium for any locus pair (based on 900 permutations, adjusted $P$-value for $5 \%$ nominal level $=$ $0.0011)$. Total paternity exclusion probability of this set of ten markers was estimated to be 0.9999 .

No locus was found to be sex-linked. The four females analysed were homozygous for loci EP20 and EP32. This might be indicative of $\mathrm{Z}$ chromosome linked loci. However, the genotyping of four more females collected in 2008 at Monteviejo (Table 1) revealed heterozygotes for each of these loci. After adding the genotype of these four females to the dataset, the overall number of alleles per locus remained the same for locus EP20, but increased from 14 to 17 for locus EP32. The addition of these samples increased the allele size range for the latter, from 185-261 to 137-261.

After genotyping ten individuals of E. meolans hispanica using the same PCR conditions, six loci amplified and five of them were polymorphic (Table 2).

\section{DISCUSSION}

Given the difficulty of obtaining useable microsatellite markers in some taxa like Lepidoptera (Meglécz et al., 2004), our study revealed a relatively high number of polymorphic loci. The number of polymorphic microsatellites previously developed for Nymphalidae species range from four (Williams et al., 2002), five (Sarhan, 2006), and eight (Cassel, 2002; Sigaard et al., 2008 and 
references therein) to 22 (Mavárez \& González, 2006) and 28 (Van't Hof et al., 2005). To the best of our knowledge, this is the third species of Satyrinae for which there are microsatellite DNA markers (cf., Cassel, 2002; Van't Hof et al., 2005).

Six out of ten of the presented loci contained a (CA) n repeat motif (Table 2), which seems to be the most common dinucleotide microsatellite in Lepidoptera (Machkour-M'Rabet et al., 2008 and references therein). Cassel (2002) and Van't Hof et al. (2005) report three out of eight and 11 out of 28 loci containing $(\mathrm{CA})_{\mathrm{n}}$ repeats, respectively. Our results were congruent with some other recent work on microsatellites in Lepidoptera, which show that at least $50 \%$ of their loci containing (CA)n repeats (Marí-Mena et al., 2008; Vila et al., 2009).

The ten markers we presented provided similar levels of variability to previous and comparable studies. For instance, the average number of alleles per locus in the Ancares population (14.30) was similar to the value found by Péténian et al. (2005) in Parnassius apollo (14), but higher than the $9.8,7.5$, and 4.7 alleles per locus reported by Vila et al. (2009), Péténian et al. (2005) and Endersby et al. (2005) using ten, six, and six microsatellites, for the moth Grallesia isabellae, the butterfly Euphydryas aurinia and moth Plutella xylostella, respectively. Concerning levels of gene diversity, the values for the Ancares (0.818) and Courel (0.812) populations were similar to the maximum estimates reported by Habel et al. (2008) for the butterfly Lycaena helle (0.49-0.83) or Endersby et al. (2006) for P. xylostella $(0.49-0.82)$.

A further problem in Lepidoptera is the frequent presence of null alleles, even for apparently clearly amplifying and interpretable microsatellite loci. This phenomenon, mostly due to high variability in flanking regions, may be related to transposition frequencies and substitution rates (Meglécz et al., 2007). In this study, EP28 and EP32 showed signs of non amplifying alleles at moderate frequencies in the Ancares population. However, only EP32 seemed to be affected by null alleles in the Courel population. Analyses of more populations are needed before drawing further conclusions about the presence of null alleles in these two markers. In the worst case, eight microsatellite loci unaffected by null alleles is a good result. Such a set of markers would be suitable for resolving many interesting questions in the field of population genetics.

A great deal of research is devoted to the study of population structure of species of Erebia: using either field-based approaches (e.g., Brussard \& Erhlich, 1970; Loertscher, 1991) or molecular techniques (e.g., Schmitt et al., 2000, 2005). In order to define a conservation unit in NW Iberia for the butterfly Erebia triaria Vila et al. (2006) used four microsatellite loci originally developed for Coenonympha hero (Cassel, 2002). These loci, although variable enough to reveal signficant differentiation of a population whose haplotypes form a divergent mitochondrial lineage, are unable to resolve the population structure at other localities (mean number of alleles per locus within populations ranged from 2.0 to 2.8 , and the overall number of alleles per locus was three or four). These same loci are monomorphic in E. palarica (Vila \& Björklund, 2004).

The development of microsatellites is usually expensive and time consuming. Our study revealed five polymorphic microsatellites for E. meolans. An interesting tool to complement a future genetic survey of this species using more highly variable markers would be the use of ISSRs. Several families of Lepidoptera have been investigated using ISSR markers (revised by Roux et al., 2007). This genetic tool has proved very useful for studying fine-scale population genetics. For instance, Luque et al. (2009) used ISSR to disentangle the genetic structure of the moth Diarsia brunnea. It revealed three sub-populations correlated with the abundance of the three host plants of the species, rather than with the sampling sites (approximately $1 \mathrm{~km}$ apart). However, few studies have compared the genetic patterns found using ISSRs and other markers. Roux et al. (2007) did this for the moth Plutella xylostella and found that despite a very high variability at the intrapopulation level, ISSR permitted differentiation of each of the populations studied. In fact, ISSR patterns can differentiate between populations that could not be differentiated using microsatellite data.

In summary, the set of ten microsatellite markers used in the present study will be useful for a variety of population genetic studies on Erebia palarica, including monitoring the genetic effects of habitat fragmentation, parental analysis and phylogeography.

ACKNOWLEDGEMENTS. We thank N. Remón and R. Pino for their valuable help in the laboratory and field, respectively. D. Romero kindly improved Fig. 1. H. Naveira supervised part of the statistical analyses. An earlier version of this manuscript was greatly improved by L. Legal and T. Schmitt. We appreciate the support provided by Ecogenics $\mathrm{GmbH}$ and the language editor of European Journal of Entomology. Permits for this work were obtained from all the relevant environmental authorities. The study was funded by grants from Xunta de Galicia (PGIDIT06PXIB103258PR), the University of A Coruna and the Galician Network of Conservation of Biological Diversity. MV was funded by Xunta de Galicia (Isidro Parga Pondal programme).

\section{REFERENCES}

Albre J., Gers C. \& Legal L. 2008: Molecular phylogeny of the Erebia tyndarus (Lepidoptera, Rhopalocera, Nymphalidae, Satyrinae) species group combining CoxII and ND5 mitochondrial genes: A case study of a recent radiation. Mol. Phylogenet. Evol 47: 196-210.

Armour J.A., Neumann R., Gobert S. \& Jeffreys A.J. 1994: Isolation of human simple repeat loci by hybridization selection. Hum. Mol. Genet. 3: 599-565.

Brumfield R.T., Beerli P., Nickerson D.A. \& Edwards S.V. 2003: The utility of single nucleotide polymorphisms in inferences of population history. Trends Ecol. Evol. 18: 249-256.

Brussard P.F. \& Ehrlich P.R. 1970: population structure of Erebia epipsodea (Lepidoptera: Satyrinae). Ecology 51: $119-129$.

Cassel A. 2002: Characterization of microsatellite loci in Coenonympha hero (Lepidoptera: Nymphalidae). Mol. Ecol. Notes 2: 566-568. 
Endersby N.M., McKechnie S.W., Vogel H., Gahan L., Baxter S.W., Ridland P.M. \& Weeks A.R. 2005: Microsatellites isolated from diamondback moth, Plutella xylostella (L.), for studies of dispersal in Australian populations. Mol. Ecol. Notes 5: 51-53.

Endersby N.M., McKechnie S.W., Ridland P.M. \& Weeks A.R. 2006: Microsatellites reveal a lack of structure in Australian populations of the diamondback moth, Plutella xylostella (L.). Mol. Ecol. 15: 107-118.

García-Barros E., Munguira M.L., Martín Cano J., Romo Benito H., Garcia-Pereira P. \& Maravalhas E.S. 2004: Atlas of the Butterflies of the Iberian Peninsula and Balearic Islands (Lepidoptera: Papilionoidea \& Hesperioidea). Monografías S.E.A. 11, Zaragoza (Spain), 227 pp.

Gautschi B., Tenzeri I., Müller J.P. \& Schmid B. 2000a: Isolation and characterization of microsatellite loci in the bearded vulture (Gypaetus barbatus) and crossamplification in three Old World vulture species. Mol. Ecol. 9: 2193-2195.

Gautschi B., Widmer A. \& Koella J. 2000b: Isolation and characterization of microsatellite loci in the dice snake (Natrix tessellata). Mol. Ecol. 9: 2191-2193.

GoudET J. 2001: FSTAT, a program to estimate and test gene diversities and fixation indices (version 2.9.3). Available at www.unil.ch/izea/softwares/fstat.html. Accessed 5 Feb 2009.

Habel J.C., Finger A., Meyer M., Schmitt T. \& Assmann T. 2008: Polymorphic microsatellite loci in the endangered butterfly Lycaena helle (Lepidoptera: Lycaenidae). Eur. J. Entomol. 105: 361-362.

Krumm J.T., Hunt T.E., Skoda S.R., Hein G.L., Lee D.J., Clark P.L. \& Foster J.E. 2008: Genetic variability of the European corn borer, Ostrinia nubilalis, suggests gene flow between populations in the Midwestern United States. J. Insect Sci. 8: 72.

LOERTSCHER M. 1991: Population biology of two satyrine butterflies, Erebia meolans (De Prunner, 1798) and Erebia aethiops (Esper, 1777) (Lepidoptera: Satyridae). Nota Lepid. (Suppl.) 2: 22-31.

Luque C., Legal L., Machkour-M'Rabet S., Winterton P., Gers C. \& WinK M. 2009: Apparent influences of host-plant distribution on the structure and the genetic variability of local populations of the Purple Clay (Diarsia brunnea). Biochem. Syst. Ecol. 37: 6-15.

Machkour-M'Rabet S., Hénaut Y., Dor A., Pérez-Lachaud G., Pélissier C., Gers C. \& Legal L. 2009: ISSR (Inter Simple Sequence Repeats) as molecular markers to study genetic diversity in tarantulas (Araneae, Mygalomorphae). J. Arachnol. 37: 10-14.

Marí-Mena N., Valade R., Magnoux E., Augustin S., LopezVAAMONDE C. 2008: Microsatellites for the highly invasive Cameraria ohridella (Lepidoptera: Gracillariidae) and their amplification in related species. Eur. J. Entomol. 105: 945-948.

Martin J.-F., Gilles A. \& Descimon H. 2000: Molecular phylogeny and evolutionary patterns of the European Satyrids (Lepidoptera: Satyridae) as revealed by mitochondrial gene sequences. Mol. Phylogenet. Evol. 15: 70-82.

MAVÁrez J. \& GonZÁlez M. 2006: A set of microsatellite markers for Heliconius melpomene and closely related species. Mol. Ecol. Notes 6: 20-23.

Meglécz E., Péténian F., Danchin E., Coeur D’Acier A., RasPLUS J.-Y. \& FAURE E. 2004: High similarity between flanking regions of different microsatellites detected within each of two species of Lepidoptera: Parnassius apollo and Euphydryas aurinia. Mol. Ecol. 13: 1693-1700.

Meglécz E., Anderson A., Bourget D., Butcher R., Caldas A., Cassel-Lundhagen A., Coeur D’Acier A., Dawson A.D.,
Faure N., Fauvelot C., Franck P., Harper G., Keyghobadi N., Kluetsch C., Muthulakshmi M., Nagaraju J., Patt A., Péténian F., Salivain J.F. \& Wilcock H. 2007: Microsatellite flanking region similarities among different loci within insect species. Insect Mol. Biol. 16: 175-185.

Munguira M.L., García-Barros E. \& Martín J. 1997: Plantas nutricias de los licénicos y satrinos españoles (Lepidoptera; Lyceaenidae y Nymphalidae). Boln. Asoc. Esp. Entomol. 21: $29-53$.

Orsini L., Corander J., Alasentie A. \& Hanski I. 2008: Genetic spatial structure in a butterfly metapopulation correlates better with past than present demographic structure. Mol. Ecol. 17: 2629-2642.

Péténian F., Meglécz E., Genson G., Rasplus J.-Y. \& Faure E. 2005: Isolation and characterization of polymorphic microsatellites in Parnassius apollo and Euphydryas aurinia (Lepidoptera). Mol. Ecol. Notes 5: 243-245.

Roux O., Gevrey M., Arvanitakis L., Gers C., Bordat D. \& LEgal L. 2007: ISSR-PCR: Tool for discrimination and genetic structure analysis of Plutella xylostella populations native to different geographical areas. Mol. Phylogenet. Evol. 43: $240-250$.

SARHAN A. 2006: Isolation and characterization of five microsatellite loci in the Glanville fritillary butterfly (Melitaea cinxia). Mol. Ecol. Notes 6: 163-164.

Schmitt T. \& Haubrich K. 2008: The genetic structure of the mountain forest butterfly Erebia euryale unravels the late Pleistocene and postglacial history of the mountain coniferous forest biome in Europe. Mol. Ecol. 17: 2194-2207.

Schmitt T. \& Seitz A. 2001: Intraspecific allozymatic differentiation reveals the glacial refugia and the postglacial expansions of European Erebia medusa (Lepidoptera: Nymphalidae). Biol. J. Linn. Soc. 74: 429-458.

Schmitt T., Varga Z. \& Seitz A. 2000: Forests as dispersal barriers for Erebia medusa (Nymphalidae, Lepidoptera). Basic Appl. Ecol. 1: 53-59.

Schmitt T., Č́̇̌žek O. \& KonvičKa M. 2005: Genetics of a butterfly relocation: large, small and introduced populations of the mountain endemic Erebia epiphron silesiana. Biol. Conserv. 123: 11-18.

Selkoe K.A. \& Toonen R.J. 2006: Microsatellites for ecologists: a practical guide to using and evaluating microsatellite markers. Ecol. Lett. 9: 615-629.

SigaArd P., Pertoldi C., Madsen A.B., SogaArd B. \& LOESCHCKE V. 2008: Patterns of genetic variation in isolated Danish populations of the endangered butterfly Euphydryas aurinia. Biol. J. Linn. Soc. 95: 677-687.

Tolman T. \& Lewington R. 1997: Butterflies of Britain \& Europe. HarperCollins, London, $320 \mathrm{pp}$.

Van Oosterhout C., Hutchinson W.F., Wills D.P.M. \& SHIPLEY P. 2004: MICRO-CHECKER: software for identifying and correcting genotyping errors in microsatellite data. Mol. Ecol. Notes 4: 535-538.

VAndewoestijne S. \& Baguette M. 2004: Genetic population structure of the vulnerable bog fritillary butterfly. Hereditas 141: 199-206.

Van't Hof A.E., Zwahn B.J., Saccheri I.J., Daly D., Bot A.N.M. \& BRAKEFIELD P.M. 2005: Characterization of 28 microsatellite loci for the butterfly Bicyclus anynana. Mol. Ecol. Notes 5: 169-172.

VILA M. \& BJöRKLUND M. 2004: Testing biennialism in the butterfly Erebia palarica (Nymphalidae: Satyrinae). Insect Mol. Biol. 13: 213-217.

Vila M., VIDAL-Romaní J.R. \& BJöRKLUnd M. 2005: The importance of time scale and multiple refugia: Incipient speciation 
and admixture of lineages in the butterfly Erebia triaria (Nymphalidae). Mol. Phylogenet. Evol. 36: 249-260.

Vila M., Cassel Lundhagen A., Thuman K.A., Stone J.R. \& BJÖRKLUND M. 2006: A new conservation unit in the butterfly Erebia triaria (Nymphalidae) as revealed by nuclear and mitochondrial markers. Ann. Zool. Fenn. 43: 72-79.

Vila M., Marí-Mena N., Yen S.-H. \& Lopez-Vaamonde C. 2009: Characterization of ten polymorphic microsatellite markers for the protected Spanish moon moth Graellsia isabelae (Lepidoptera: Saturniidae). Conserv. Genet. DOI 10.1007/s10592-009-9905-1.

WagNer H.W. \& SEFC K.M. 1999: IDENTITY 1.0. Centre for Applied Genetics, University of Agricultural Sciences, Vienna. Available at www.uni-graz.at/ sefck/ Accessed 8 May 2009.
WARREN B.C.S. 1936: Monograph of the Genus Erebia. British Museum (Natural History), London, 407 pp.

Weller J.I., Seroussi E. \& Ron M. 2006: Estimation of the number of genetic markers required for individual animal identification accounting for genotyping errors. Anim. Genet. 37: 387-389.

Williams B.L., Brawn J.D. \& Paige K.N. 2002: Highly polymorphic microsatellite loci for Speyeria idalia (Lepidoptera: Nymphalidae). Mol. Ecol. Notes 2: 87-88.

ZHANG D-X. 2004: Lepidopteran microsatellite DNA: redundant but promising. Trends Ecol. Evol. 19: 507-509.

Zhang Z., Schwartz S., Wagner L. \& Miller W. 2000: A greedy algorithm for aligning DNA sequences. J. Comput. Biol. 7: 203-214.

Received June 22, 2009; revised and accepted August 4, 2009 